\title{
E-Comics as an Interactive Learning Media on Static Fluid Concepts
}

\author{
Dewi Atikah Suri*, Irnin Agustina Dwi Astuti, Yoga \\ Budi Bhakti \\ Department of Physics Education \\ Universitas Indraprasta PGRI \\ Jakarta, Indonesia \\ *atikahsuridewi@gmail.com
}

\author{
Ria Asep Sumarni \\ Department of Informatics \\ Universitas Indraprasta PGRI \\ Jakarta, Indonesia \\ riaasepsumarni@gmail.com
}

\begin{abstract}
Physics learning on fluid concepts seems abstract, making students le Physical material about fluids makes many students less understanding because the material is very abstract, and there are many physics formulas. Therefore it takes a learning medium for physics learning to become interactive and keep students active in the classroom. E-comic is one of the learning media in accordance with the current technological development. This study aims to find out the service of e-comic as a medium of physics learning. Research using research and development methods with ADDIE model (analysis, design, development, implementation, evaluation). The results showed android-based e-comic is worth using in physics learning with an average validation score of 83.8. E-comics is one of the innovations of learning media in the digital age that can be implemented to students and used without any restrictions on space and time.
\end{abstract}

Keywords—e-comic, android, physics learning media

\section{INTRODUCTION}

One of the materials from physics lessons is fluid material which is one of the materials that is included difficult according to most students. In solving the problem of fluid concepts must be related to the concept of pressure and in daily life $[1,2]$. From the results of the analysis of the mastery of the material on the National Exam (UN) by the National Standards Board of Education that the absorption that describes the percentage of students' correct answers to the questions that high school students do in Jakarta for physics lessons on fluid materials is 63 . This indicates that students have not been able to absorb fluid material properly.

Based on the observation results through interviews with physics teachers, it can be seen that the interest level of physics learning is deficient due to the input of students who are low/ incapable in learning to understand the concept of physics. Consistently input students, then, in the end, the students switch to gadgets (mobile phones) and then play it. In this school, most teachers also allow their students to use mobile phones or gadgets because it is thought to facilitate learning so that it becomes effective in finding and adding materials related to the subjects. However, it is not practical because in its use the students do not learn about lessons. Still, instead, they open up many useless things such as games, social media, even online shops and it is all played in the classroom during the learning activities. However, the school facilities that have been used, such as the availability of school Wifi, students still can not understand the physics learning activities that are expected to be fun. Because in addition to being due to student input, the learning media rarely used by teachers also affects, the delivery of material that is very monotonous and boring that makes students do not understand the material so many of the students do not like physics lessons and ultimately make the level of interest of students very low in physics lessons.

In general, to increase interest in physics lessons, students must understand the concepts of physics very well and related to gadgets $[3,4]$. In the concept of physics, analysis and depiction are required in understanding it [5-7]. Images are a visual form of understanding something, one of the conditions of the image to apply the concept of physics that is to use android-based digital comics as a learning medium. One of the learning media that can be used in learning is comics. Comics are a medium consisting of fictional and non-fiction ideas delivered through visual images to explain the course of a story [8]. Comics can enhance and enlarge communication by facilitating readers to create their understanding. In this era, the limited number of comics in the mass media is explicitly scientific [9].

Where in this era of 4.0, advances in science and technology such as gadgets are thought to be very helpful as a platform for android-based digital comics using several comic maker apps [10,11]. Creating digital comics using several applications such as Comic Life 3, Adobe Photoshop CC, and Pixton can increase students' interest in understanding physics materials and can pack physics learning into more exciting and fun for students. Thus, android-based physics digital comics can be used for the students. As in Entobuo's research about development of comic digital for physcs learning. The science comic uses the Toondo app in the making, the images already available in the app make the comic a little monotonous and 
the low level of readability of the text makes it a weakness in itself [12]. Meanwhile, digital comics that we create using various applications such as comic life 3, adobe photoshop CC, and Appy pie that makes media in the form of android applications have the advantage in creating and editing images of characters and text that we need. Besides, the stories in the comics applied in the android platform can support students in understanding the material taught. The novelty of this research is to develop e-comic learning media that can be used in physics learning. In static fluid material, there is no such thing as learning media in the form of e-comic. In e-comic, there is a lot of content such as physics comic stories, a summary of static fluid material, sample questions, practice questions, and online learning evaluation.

\section{METHODS}

The research method conducted is a development research method using ADDIE model covering five stages, namely analysis stage, planning stage, development stage, implementation stage, and evaluation stage. This research is only in the development stage, because the goal is only to make android-based e-comic products.

This research was conducted to develop e- comic media in science learning in style and motion material. Product eligibility assessments are tested and assessed by the validator, i.e., media experts, material experts and linguists. The data analysis technique used in this study is a descriptive analysis by calculating the percentage of validation result value.

\section{RESULTS AND DISCUSSION}

Android-based e-comic creation requires Comic Life 3, Appypie, Pixton, and Adobe Photoshop CC 2018 apps that are used to design and edit the images you need. The Comic life 3 apps are used to create storylines in the form of comics featured in comic strips so that they appear per page. While Adobe Photoshop CC 2018 is used to create an environment or image in comics. Added character images in comics using Pixton. Once all the material and image needs are complete, the next stage is the creation of android-based e-comics using Appypie. Once the application has been completed then the next step is to trial the program before the e-comic is assessed by experts for validation.

The next step is to validate the e-comic. The validation of digital comics is done by providing questionnaires to experts who are divided into three media experts, material experts, and language experts. The results of the validation of the media expert assesment on the product can be seen in the Figure 1.

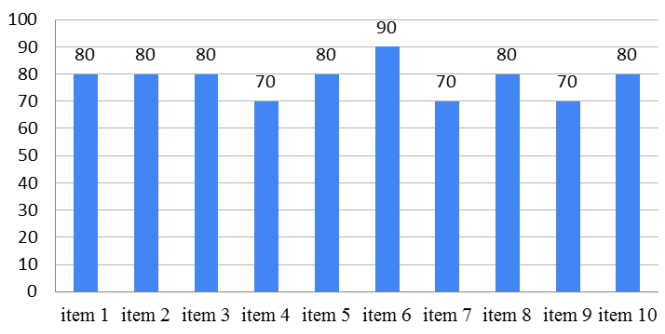

Fig. 1. The result validation of media expert.

From the validation test results by media experts get the results of the chart as in Figure 1. The minimum value obtained based on the expert questionnaire is $70 \%$, and the maximum value obtained is $90 \%$ with excellent interpretation. If average, then the score is $79 \%$ with the right performance and worth testing in school. Advice and input from media experts then researchers fix so that e-comics can be applied in physics learning. The results of the validation of the material expert assesment on the product can be seen in the following Figure 2 .

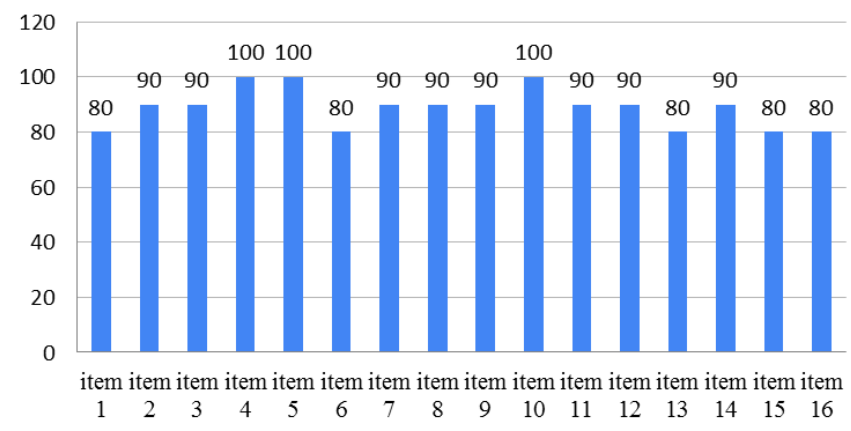

Fig. 2. The result validation of material expert.

From the validation test results by media experts get the results of the chart as in Figure 2. The minimum value obtained based on the expert questionnaire is $88 \%$, and the maximum value obtained is $100 \%$ with excellent interpretation. If average, the score is $88 \%$ excellent and worth applying in physics learning in school. The results of the validation of the language expert assesment on the product can be seen in the Figure 3.

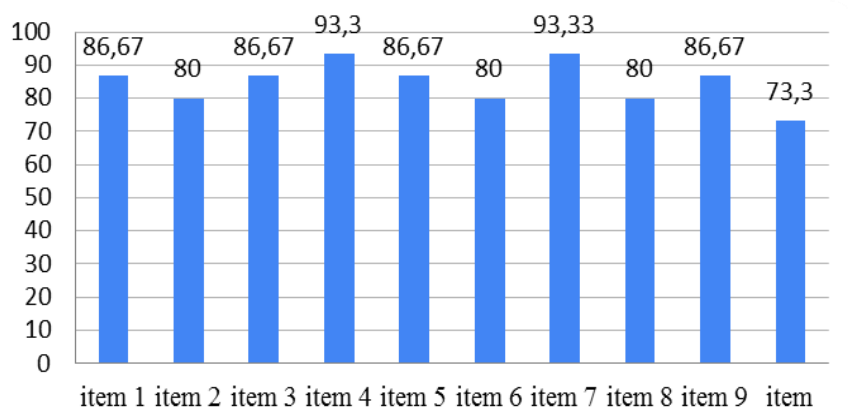

Fig. 3. The result validation of language expert. 
From the validation test results by the language expert get the results of the chart as in figure 3 . The minimum value obtained based on the expert questionnaire is $73.3 \%$, and the maximum value obtained is $93.33 \%$ with excellent interpretation. If average, the score is $84.6 \%$ excellent and worth testing in school.
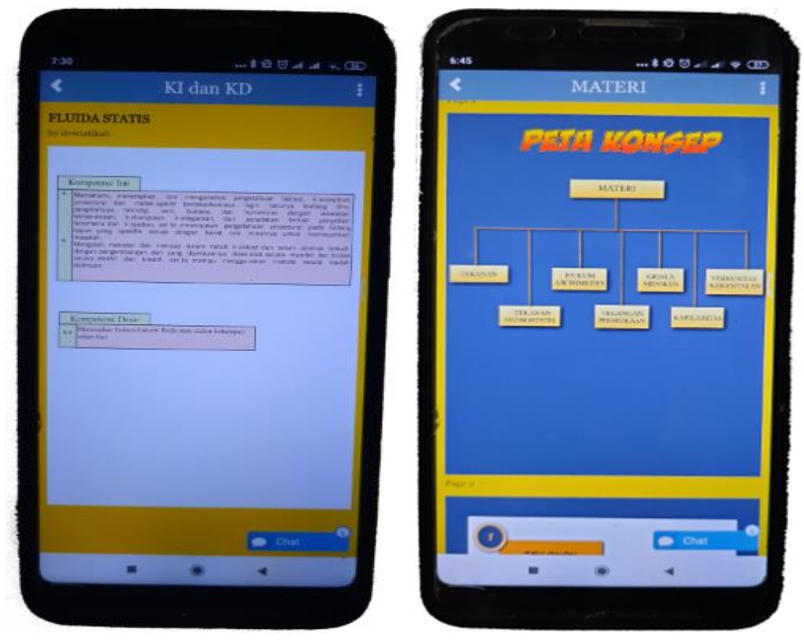

Fig. 4. Indicator layout and mind mapping.

Once you've logged into the e-comic app, there will be several menus. Inside is a menu of indicators, concept maps, materials, comics, and evaluations. On the e-comic menu, there is a menu of core competencies and basic competencies and a concept map that can display sub-material physics, showed in figure 4 .

The material contained in the e-comic is a comic story and a summary of physics material about static fluid. The content of e-comic stories uses language that is easy to understand and communicative. The images contained in the comics are more interesting that show funny e-comic characters and comic story settings according to daily life, showed in figure 5.
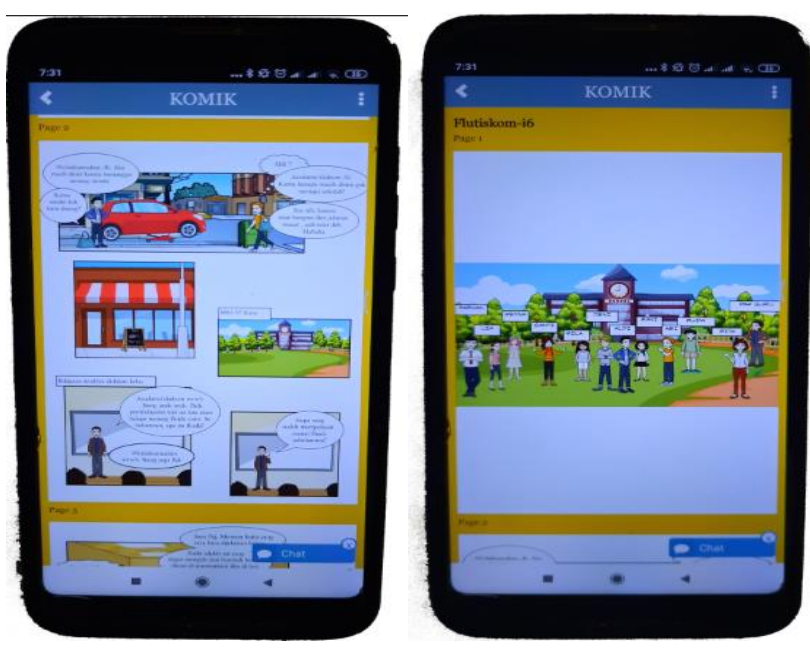

Fig. 5. Display of comic contain
The content of comic stories displays the physics material conveyed in the form of stories that are easily understood by students. The story is made with simple language and is applied according to everyday life, so the physics material is attributed to the real world. In the comic also shows examples of physics and discussion, as well as the practice of multiplechoice evaluations to see the ability of physical material in students.

Learning physics by using e-comics can increase students learning activities and students' learning interests [13]. According to Ari stated that learning with comics will increase students' learning and literacy interests $[14,15]$. Students will be enthusiastic about reading the content of comic material and the course of the story in the comics.

Comics are powerful visual messages that convey the meaning of a story with short and clear $[16,17]$. Comics is alternative instructional materials for teachers to attract students attention and help them studying easily and practically as it provides an interesting illustration with simple language [18-20]. All of the teachers strongly agreed that comics could be used as learning media since the visual images in comics could motivate students to learn, especially if the comics are attractive and contain knowledge [21].

The function of digital comics is to provide clear direction regarding the learning process [22]. Students become motivated to learn and read given digital comics. In studying physics, students can access e-comics using a smartphone. So that phenomenon allows students to learn anywhere [23]. From e-comic learning, students should find problem-solving from the case or the course of the story in the comics [24,25].

The advantage of this android-based e-comic is that comic stories' content can be well understood because it is associated with daily life. There are comic animations that can explain abstract fluid materials, and there are evaluations to know students' ability to understand fluid material. With the arrival of android-based e-comics, students are expected to understand the concept of static fluid physics and build creativity, and have critical and imaginative thinking skills. Besides, with the comic, it is hoped that learning can take place well and effectively. So it will be able to increase students' interest and motivation in physics subjects, especially static fluid materials. E-comics can be applied in schools; they can use smartphones and laptops during lessons only if they get permission from the school. However, the implementation of e-comics takes time because some students do not have smartphones or laptops, and students need to adapt first to e-comic learning.

\section{CONCLUSION}

Based on the study results, it can be concluded that this ecomic learning medium is included in the standard "good" or worthy of use as a medium of physics learning. Due diligence conducted by material experts, media experts, and language experts obtained an average validation value of 83.8. E-comics is one of the innovations of learning media in the digital age 
that can be implemented to students and used without any restrictions on space and time.

\section{REFERENCES}

[1] S. Sularso, W. Sunarno, and S. Sarwanto, "Understanding students" concepts through guided inquiry learning and free modified inquiry on static fluid material," in International Journal of Science and Applied Science: Conference Series, vol. 2, no. 1, pp. 363-367, 2017.

[2] L. Sun, H. Gao, S. Pan, and J.-X. Wang, "Surrogate modeling for fluid flows based on physics-constrained deep learning without simulation data," Comput. Methods Appl. Mech. Eng., vol. 361, p. 112732, 2020.

[3] G. Schwabe and C. Göth, "Mobile learning with a mobile game: design and motivational effects," J. Comput. Assist. Learn., vol. 21, no. 3, pp. 204-216, 2005.

[4] I.A.D. Astuti, D. Dasmo, N. Nurullaeli, and I.B. Rangka, "The impact of pocket mobile learning to improve critical thinking skills in physics learning," J. Phys. Conf. Ser., vol. 1114, no. 1, 2018.

[5] J.R. Batlolona, C. Baskar, M.A. Kurnaz, and M. Leasa, "The improvement of problem-solving skills and physics concept mastery on temperature and heat topic,” J. Pendidik. IPA Indones., vol. 7, no. 3, pp. 273-279, 2018

[6] M. Planinic, Z. Milin-Sipus, H. Katic, A. Susac, and L. Ivanjek, "Comparison of student understanding of line graph slope in physics and mathematics," Int. J. Sci. Math. Educ., vol. 10, no. 6, pp. 1393-1414, 2012.

[7] Y.B. Bhakti, "Integrated STEM Project Based Learning Implementation to Improve Student Science Process Skills," in Journal of Physics: Conference Series, 2020, vol. 1464, no. 1, p. 012016

[8] P.C. Toh and B. Kaur, Developing 21st century competencies in the mathematics classroom. World Scientific, 2016.

[9] P.D.A. Putra and M. Iqbal, "Implementation of digital comic to improve creative thinking ability in integrated science study," Interaction, vol. 4 p. 3, 2014.

[10] U. Rohaizati, "Junior secondary school teachers and students' needs for the use of digital comics in learning mathematics," in Journal of Physics Conference Series, 2020, vol. 1460, no. 1, p. 12026.

[11] H. Purnamasari, S. Siswoyo, and V. Serevina, "Pengembangan Media Pembelajaran E-Komik Pada Materi Dinamika Rotasi," in Prosiding Seminar Nasional Fisika (SNF), 2018, vol. VII, pp. SNF2018-PE-29SNF2018-PE-35.

[12] N.E. Ntobuo, A. Arbie, and L.N. Amali, "The development of gravity comic learning media based on Gorontalo culture," J. Pendidik. IPA Indones., vol. 7, no. 2, pp. 246-251, 2018
[13] A.D. Lesmono, R.W. Bachtiar, M. Maryani, and A. Muzdalifah, "The Instructional-Based Andro-Web Comics on Work and Energy Topic for Senior High School Students," J. Pendidik. IPA Indones., vol. 7, no. 2, pp. 147-153, 2018.

[14] D. Yulianti, S. Khanafiyah, and S. Sulistyorini, "Inquiry-based science comic physics series integrated with character education," J. Pendidik. IPA Indones., vol. 5, no. 1, pp. 38-44, 2016.

[15] M. Bitz, "The comic book project: Forging alternative pathways to literacy," J. Adolesc. Adult Lit., vol. 47, no. 7, pp. 574-586, 2004.

[16] J.S. Park, D.H. Kim, and M.S. Chung, "Anatomy comic strips," Anat. Sci. Educ., vol. 4, no. 5, pp. 275-279, 2011.

[17] H.-Y. Phoon, R. Roslan, M. Shahrill, and H.M. Said, "The role of comics in elementary school science education," Form. J. Ilm. Pendidik. MIPA, vol. 10, no. 2, 2020.

[18] A. Arroio, "Comics as a narrative in natural science education," West. Anatolia J. Educ. Sci., pp. 93-98, 2011.

[19] M.M.D. Yunus, H. Salehi, A. Tarmizi, and S.F. Syed, "Using Digital Comics in Teaching ESL Writing," Proc. 2nd Int. Conf. Arts Cult. (ICAC 11), pp. 53-58, 2011.

[20] F. Lazarinis, A. Mazaraki, V.S. Verykios, and C. Panagiotakopoulos, "E-comics in teaching: Evaluating and using comic strip creator tools for educational purposes," 10th Int. Conf. Comput. Sci. Educ. ICCSE 2015 , no. Iccse, pp. 305-309, 2015.

[21] I.N. Hidayah, "Development of Math Comic Learning Media on The Subject of Algebraic Expressions for Seventh Grade of Junior High School Students," in Journal of Physics: Conference Series, 2019, vol. 1227 , no. 1, p. 12029.

[22] S.M. Bullock, "Using digital technologies to support Self-Directed Learning for preservice teacher education," Curric. J., vol. 24, no. 1, pp. 103-120, 2013.

[23] D. Muliyati, D. Rahmadini, and S. Siswoyo, "The development of digital comics to explain the photoelectric effect through biographies and history," in Prosiding Seminar Nasional Fisika (SNF), 2019, vol. 3, pp. 147-154.

[24] W.N. Azmy, A.E. Damayanti, H. Kuswanto, and B. Susetyo, "Learning optics with android-assisted comics: the impacts on students critical thinking," in Journal of Physics: Conference Series, 2020, vol. 1440, no. 1, p. 12055

[25] A.E. Damayanti and H. Kuswanto, "The use of android-assisted comics to enhance students' critical thinking skill," in Journal of Physics: Conference Series, 2020, vol. 1440, no. 1, p. 12039. 